\title{
'Quis custodiet ipsos custodes?' (Juvenal Satires:§345) (Who guards [nurtures] the guardians?): Developing a constructivist approach to learning about ministerial and spiritual formation
}

\author{
Author: \\ Graham A. Duncan ${ }^{1}$ \\ Affiliation: \\ ${ }^{1}$ Department of Church \\ History and Church Polity, \\ University of Pretoria, \\ South Africa \\ Correspondence to: \\ Graham Duncan \\ Email: \\ graham.duncan@up.ac.za \\ Postal address: \\ Faculty of Theology, \\ University of Pretoria, \\ Pretoria 0002, South Africa \\ Dates: \\ Received: 29 Mar. 2012 \\ Accepted: 14 June 2012 \\ Published: 06 Sept. 2012 \\ How to cite this article: \\ Duncan, G.A., 2012, "'Quis \\ custodiet ipsos custodes?" \\ (Juvenal Satires:§345) \\ (Who guards [nurtures] the \\ guardians?): Developing a \\ constructivist approach to \\ learning about ministerial \\ and spiritual formation', \\ HTS Teologiese Studies/ \\ Theological Studies 68(1), \\ Art. \#1251, 7 pages. http:// \\ dx.doi.org/10.4102/hts. \\ v68i1.1251
}

(c) 2012. The Authors. Licensee: AOSIS OpenJournals. This work is licensed under the Creative Commons Attribution License.
The main purpose of this exercise was to develop an improved model of ministerial and spiritual formation in the training of ministers in the Uniting Presbyterian Church in Southern Africa at the University of Pretoria. This is a perennial problem in many churches where there is a general dissatisfaction with the products, (i.e. ministers) not only in terms of personal spirituality but in their inability to minister effectively in the many diverse situations to which they are called or appointed. The exercise of power becomes an issue in a vocation which is premised on servant ministry and so Juvenal's quotation is apt as it is expressed as 'Who can be trusted with authority/power?'.

\section{Introduction}

Kretzschmar (2006:341) stated that the Christian church in Africa is currently experiencing a shortage of spiritually aware, competent, credible and prophetic leaders.

In accepting the general truth of this statement, the main purpose of this exercise was to develop an improved model of ministerial or spiritual formation in the training of ministers in the Uniting Presbyterian Church in Southern Africa at the University of Pretoria, in a context in which ministers of a number of churches study. The problem inherent in ministerial formation is a perennial problem in many churches where there is a general dissatisfaction with the products (i.e. ministers) not only in terms of personal spirituality, but in their inability to minister effectively in the many diverse situations to which they are called or appointed (cf. Naidoo 2008:128). This is true to the extent that there is 'a noticeable lack of direction and common purpose' (Kretzschmar 2006:342). In addition, a common problem is the naive, pre-critical, sentimental or fundamentalist piety which students bring to their formation period. At the end of the process, products of the academy are academically well qualified in terms of knowledge and skills, but their academic knowledge does not appear to be transferable largely because a knowledge-based education is given. This can produce a minister who does not have a discernible integrated identity and who views his ministry as any other job - a profession rather than a vocation. Consequently, the time is ripe for experimentation with an outcomes based model. On a personal level, my own practice, largely teacher-tell, and my experience is archaic. It is possible to involve others with more relevant up to date experiences, but this is still the experience of others and not that of the learners. The learners need fresher input - their own, on which to base their own personal development. And because their experience in ministry was limited, their practice needs to be developed through experimentation so that it might be 'meaningful and relevant to [their] experience' (McNiff 2002:8). Yet, this needs to be guided, inquiry-based learning which requires a variety of teaching methods all of which demand learner participation:

The students are presented with problems to be solved, the learning process is emphasised, and the teacher becomes a guide through the process. This teaching method gives the students a sense of ownership of what they learn, and stimulates their engagement and creativity. (Dysjeland 2012:38)

\section{Theoretical framework}

The question posed in the title expresses a perennial problem in the education and formation of ministers. 'In Protestant theological institutions formation is more likely to be pursued through individual faculty contributions and extra-curricular activities' (Naidoo 2008:129), that is it is predominantly unstructured and left to chance. Then there is the problem of the relation of spiritual formation to other aspects of training, in particular the academic, with a smattering of pastoral exposure. Ministers are prepared for a life of service to the community as spiritual leaders and carers. They are expected to fulfil a multitude of roles and become relatively competent in 
all of them - a 'jack of all trades', 'Multiple Roles' (Hattingh \& De Kock 2008:326) approach. They are subjected to the stresses and anxieties of those whom they serve in addition to their own stresses, and the greater part of their education is in the academic domain. In order to be effective carers they have their own needs that have to be attended to as part of their formation (cf. the principle that those who are to be psychoanalysts must undergo analysis themselves first): 'The spiritual maturity of future Christian leaders is an important challenge and needs to be addressed throughout theological training' (Naidoo 2008:128) and beyond by the development of a life-long approach to learning. Important aspects of this process involve self-knowledge and the nature of one's own spiritual life, knowledge of the tradition and an understanding of human behaviour. Within an intercultural community, there are particular challenges, for example differences in tradition. This is especially challenging when many candidates for the ministry have 'little or no sense of the history, customs and ethos of the religious communities that they feel called to serve and lead' (Naidoo 2008:136). This may be the result for many current students, who are candidates for ministry, coming from previously unchurched contexts. All of this concurs with the active constructivist learning approach that proposes that the educator facilitates learning and the learners construct their own meanings.

A further problem area is that ministry is exercised in a rapidly developing dynamic context (Preece 2005:1; Candy 1996 in Walters 1999:577). Earlier views centred on an understanding of a world that was either static or changed slowly and that therefore, ministry training equipped a person for ministry for life and that professional development was complete on ordination. That situation no longer exists and ministry, like most other professions and vocations, is a process of life-long learning.

Even in the field of Practical Theology (theology of ministry) the primary focus is on acquiring knowledge rather than skills and values (ethics: code of conduct) which can inform and guide their practice. Although the term praxis is commonly employed, it is not fully or appropriately understood. Yet, it offers a teaching or learning approach that is consonant with contemporary educational principles. Thomas Groome, a Christian educationist, pioneered such an approach in the field of Christian education from the 1970s when I was involved in seminary theological education in South Africa. Groome (whose work is based on Piaget's cognitive development theory) premised an entire teaching or learning approach to Christian education on a shared praxis model where praxis (a cyclical and holistic model) is:

'reflective action', that is, a practice informed by theoretical reflection, or, conversely, a theoretical reflection that is informed by practice ... The term praxis attempts to keep theory and practice together as dual and mutually enriching moments of the same intentional human activity. (Groome 1980:xvii, fn.1)

He later summarises it as 'purposeful, intentional, and reflectively chosen ethical action' (1980:152).

When it comes to matters of content, Church authorities normally decide what learners are required to know, the skills they must master and the values they must develop and then they closely define the courses and methods their candidates must follow. For the most part this is based on the previous experience of their mentors which is often out of date (i.e. the experience of others or old memories). This is frequently based in an authoritarian form of leadership and is often inflexible. Critique and challenges, arising out of reflection on the multifarious contexts of ministry are normally perceived as threatening to those in authority. In this context and in the wider arena Kretzschmar (2006:342) refers to 'a reluctance on the part of ministers to critique unwise or corrupt political leadership.' This reluctance extends to a fear of critiquing the institutional church and its leadership. This form of leadership is ingrained and not easily susceptible to change or modification.

A new approach can be based on the historical memories and lived and living experience of the candidates themselves where:

experience is primarily an act of interpretation. Experience is not an immediate act of consciousness or some feeling underlying human thoughts and concepts. Instead experience takes place within the context of memory, the memory of previous examples and similar cases. Moreover, experience is embedded within a cultural tradition and a network of social interaction and mutual interpretation. Memory, tradition and interpretation are as much a part of experience and as determinative of experience as are the acts of consciousness, sensation, or feeling. Experience is therefore not merely a perception of something immediate, but rather an interpretation dependent on knowledge and memory. (Fiorenza 1984:296, 298)

Therefore, praxis is necessarily narrative oriented:

praxis ... always involves an essentially narrative structure ... By means of stories of the self and of the world around us we hold together events, persons and experiences that would otherwise be fragmented. (Gerkin 1986:52)

Drawing on Aristotle, Groome (1991:46) suggests that memory and imagination are symbiotic activities 'with imagination drawing its images from what is already in memory by a process of imitation (mimesis.)' This will form part of the investigation related to role modelling in ministerial practice and this leads naturally to the 'development of spiritual and moral leaders who are competent and mature people of integrity' (Naidoo 2008:130; cf. Kretzschmar 2006:341) who have submitted to a process of 'sanctification, of becoming Christian, and shaping Christian character' (Naidoo 2008:131). Spiritual formation is an intentional process of formation and integration and it must also be observable in the contexts of practice. It is not the result of pursuing and completing a number of courses successfully but rather a process of critical reflection and integration (Lamoureux 1999:143).

Rather than subjecting learners to formal examinations, which are not in tune with accountability in the contemporary world, the practice of preparing a portfolio is more appropriate as a learning tool. The theoretical part of the portfolio can be based on works which contribute to the formation of a theoretical framework on the overarching strategy to be employed, based on Action Research theory (Hodgkinson \& Maree 
1998), Shared Praxis (Groome 1980, 1991), Constructivist Learning theory (Gagnon \& Collay; McNiff 2002), Multiple Intelligences (Gardner 1983), Collaborative Research (Cooper 2000-2006), Holistic Learning (Copley 2009), Multi-cultural education (Gorski 2004b \& 2004c), teaching and learning strategies including Herrmann's Whole Brain Development Theory (De Boer, Steyn \& Du Toit 1999), Kolb's (1984) learning style model and Felder's (Felder \& Soloman n.d.) learning styles and strategies.

This approach will not be premised on a know-everything approach but will concentrate rather on developing a model or methodology on which ministry practice (engagement) can be based which includes the growth of knowledge, skills and values.

\section{Aim}

The aim of the proposed constructivist and holistic approach is to design a model for the education of the whole person in the Christian faith ministry. Knowledge of faith matters is not just an intellectual engagement. Groome (1980:56-65) treats it as believing, trusting and doing which brings it into the realm of skills and attitudes and values. It can be enhanced by an understanding and implementation of Hermann's whole brain teaching and learning model (De Boer et al. 1999) and multiple intelligence theory (Copley 2009:72ff.). Then it may promote critical reflection, ethical action and imaginative creativity as a foundation for individual and social praxis. In order for such a model to be fully integrated, it is vital that the learners participate in the structuring and development of the model that is, they need to buy into the idea through a commitment as the result of discerning a need to re-envision their (ministers') 'values and intentions in living our [Christians'] lives' (McNiff 2002:13) and so to 'contribute to the formation of a better society' (McNiff 2002:27) that is through transformation of self, since change is here to stay and this will certainly challenge traditional views for:

we have to believe that it is possible to change things, otherwise we might as well give up right now on every effort and programme to improve the quality of life ... If we live in hope at least we have some idea of what we can achieve. (McNiff 2002:27)

The aim is 'ongoing analysis, prayer, honest self-reflection, considered listening to others, rigorous implementation and renewed analysis' (Kretzschmar 2006:342). This can help to meet the need discerned by Greenleaf (1977):

Churches are needed to serve the large numbers of people who need mediative help if the alienation is to be healed and the wholeness of life achieved, but I regret that, for the most part, churches do not seem to be serving well. They can be helped to do much better. And they can be helped to become servant leaders - by being exemplars for other institutions. (pp. 218-219)

This is the essence of action research.

\section{Action research}

Action research is a self-reflective participative investigation into one's own and learners' practice with the aim of improving and refining performance and experience. It begins with the identification of a problem, the formulation of hypotheses regarding possible improvement, experimentation, reflection on the outcome and modification of practice leading to further action. It is systematic and iterative (it is continually checking) in the sense that it is cumulative in its effect on practice (Hodgkinson \& Maree 1998:52-53). The use of action research in theological education has been attested by Wingate (2010:223; cf. Ruiz 2010:275) in a pluriform context - social, political, religious (a multi-faith world) and cultural:

The major characteristics of this paradigm are related to the inter-disciplinary and trans-disciplinary, to various forms of knowledge and the possibility of putting them in relation and articulating them with the historical context, to its transforming and innovative character and above all to an ongoing process like an upward spiral on the basis of successive, contextual and permanent revisiting interpretations. (Preismerk \& Buehler 2010:290)

The growth and development of the individual - both learner and facilitator - is the core of the process (McNiff 2002:6). This requires that teaching and learning models 'embrace more active-learning models, and shifts toward intentionally interdisciplinary and cross-disciplinary teaching oriented toward praxis [which] may prompt a renewal of theological education as a habitus for lifelong learning' (Myhre 2010:297). Such a prospect is a distinct possibility: 'Maybe a habitus for theological education is emerging that will embrace an individual's education, their communal context, and their wider ecclesial location in a matrix of lifelong learning' (Myhre 2010:301).

Action research requires learners to take responsibility for their own learning and needs to be grounded in 'democratic practices, care and respect for the individual, and the need for disciplined enquiry' (McNiff 2002:8) leading to improved performance which requires frequent evaluation (formative and summative assessment). Consequently, it is value-based as well as focussing on knowledge and skills development. This provides both a theoretical and practical framework for learning.

\section{Research questions}

Juvenal's historic, yet amazingly relevant question, takes us to the heart of ministerial formation. What is it for? It is for leadership. What is an appropriate approach (model) to use in the spiritual and vocational formation (teaching or learning) of ministers? - How does leadership develop within a community?

This will involve a needs or situation analysis of the local church context in which the learners work to ascertain the social problems that they might encounter which require decision making when designing a blended learning (Garrison \& Kanuka 2004) environment, and be equipped to do the best job possible in the communities they serve and integrate the teaching or learning model into their practice as an alternative to the forgetfulness which derives from other 
models. It is also a model that is being promoted strongly in tertiary education. The model will focus on achieving deep meaning and deep learning through an enquiry-led approach. Assessment is an important dimension of such a design in working towards leadership development in the community. This will happen through learner feedback and evaluation particularly with regard to how the learners experience the learning process and how it enhances their level of understanding. This will be a collaborative exercise where the facilitator, mentor or supervisor will also have an opportunity to critique their own practice as part of the process of their own professional development through selfreflection (meta-cognition) and reorientation of their own practice in facilitating learning in the context of spiritual or ministerial formation.

\section{This leads to related sub-questions:}

- Do the tasks of ministry contribute to ministerial or spiritual formation?

- What methodology will provide the best teaching or learning opportunities: role play, drama, actual community work?

- What will the nature of the content look like: what are the prime tasks of ministry?

- What is the level of the learners - undergraduate?

- What are the specific and critical outcomes aimed at? (See below)

\section{Critical outcomes}

These outcomes encapsulate the skills knowledge and values or attitudes that contribute to the personal ministerial faithfulness (recognised as success in the secular world). The overall curriculum design for learning needs to integrate the critical outcomes:

- Reflect on your own understanding of ministry and what makes up a good process for vocational development and use a variety of strategies to become an able practitioner.

- Solve problems presented in ministry practice, in class or through observation using critical and creative thinking.

- Work collaboratively with other congregational leaders to develop ministry within the concept of the 'priesthood of all believers'.

- Collect, analyse, organise and critically evaluate information regarding ministry practice and your own practice.

- Communicate effectively as a congregational facilitator of learning (teaching elder) using a variety of media for preparing material and reports.

\section{Research design and methods}

Groome's shared praxis model (based on Piaget's genetic epistemological research (1980:239ff.), can be integrated with a constructivist learning approach as students 'are engaged in active learning and making their own meaning and constructing their own knowledge in the process' (Gagnon \& Collay n.d.:2) through experience. Both are based on Aristotle's empirical epistemology (Groome 1980,1991) and are closely linked with active learning. Based on the uniqueness of the individual it is possible to integrate shared praxis as a part of the learning process. It aims to develop the learner by engaging with truth from within his own culturally embedded context (i.e. history and tradition) including knowledgeable people (e.g. teachers and peers) aiming at effective intuitive thinking and deep learning, which construct social and cultural reality. The teaching role is that of a facilitator (ask rather than tell, provide guidelines, create an environment for learning, dialogue) and mentor (through cognitive apprenticeship). In this process, there is a need for collaborative learning (Cooper 2000-2006). Knowledge is an integrated whole, that is it is holistic. Therefore it is appropriate to explore and implement the theory of Multiple Intelligences.

In a constructivist approach to education, the process begins with the design of a situation based on assessment of learners' needs; the formation of groupings based on available materials and the desired mix of learners; a bridge between what is known and what is aimed at; questions to ask and answer, leading to the production of an exhibit, a record of thinking by sharing it and asking for others' reflections about learning. This requires collaborative work and is appropriate for team teaching in a multicultural setting (Gross Davis 1999:3, 5).

Part of any holistic model operating in the South African context must take account of a multicultural approach to education (cf. Constructivism n.d.; Derek Bok Center 2004). This is vital since the learner groups come from a variety of South African backgrounds but are predominantly Black learners who come from disadvantaged rural backgrounds. The work of Gorski and Covert (1996, 2000, 2004:1) demonstrates the constructive approach whereby individuals 'tend to mo[u]ld concepts to fit their particular focus'. It is important to incorporate Hernandez' assumptions, goals and principles of multicultural education as defined by Gorski (Gorski \& Covert 2004:3) who offers helpful tools for teacher self-assessment and necessary paradigm shifts (Gorski 2004c) in a multicultural context.

A combination of Groome and Gagnon, and Collay's approaches, along with Kouzes' and Posner's (2004) approach to leadership formation, was employed using the stories (narratives) of the learners; their experiences of ministry, that is through observation, being ministered to and ministry exercised by them. These were supplemented with written material drawn from scripture, contextual sources (predominantly from the South African context) and others' experiences. The learners were encouraged to interrogate these experiences with the aim of developing a personal praxis of ministry and spiritual formation. Other research methods included observation and questionnaires, see Table 1.

This process was initiated by planning an initial learning opportunity in the light of research questions and theories of teaching and learning with regard to ministerial or spiritual formation. This was a negotiated opportunity with 
TABLE 1: Constructivist approaches to ministerial formation praxis.

\begin{tabular}{lll}
\hline Groome: Shared praxis & Gagnon and Collay: Constructivist learning & Kouzes and Posner \\
\hline Naming present action & Situation, questions (HIBD: A, D) & Model the way \\
(this may include questions regarding what learners already know about a topic, what they want to learn and a desire on their part to participate in the teaching process [Gorski 2004c:1]) & Inspire shared vision \\
Critical reflection & Groupings, questions & Challenge the process \\
Dialogue & (group dynamics, HIBD:C) Bridge, reflections, questions & Enable others to act \\
The Story & Exhibit, questions & Encourage the heart \\
The Vision & Exhibit, questions &
\end{tabular}

both the teacher's and learners' perception of their needs (situation), to avoid the imposition of needs that may not be felt or experienced. Then there was the formation of a bridge between the already known and the aim:

- What constitutes ministerial or spiritual formation? (content)

- Is present practice appropriate? (Analysis and critique)

- What alternatives can be attempted?

This was followed by planning specific learning opportunities, for example leadership, using the overarching model for instructional design (Du Toit 2009a:29-35) which included planning instruction, executing (managing) these opportunities, delivering instruction, assessing instruction and planning further opportunities related to specific aspects of ministry education. The learner priorities which emerged in ministry were preaching, sacraments, pastoral care and church administration.

This process is aimed at 'deep-learning' which seeks understanding, re-evaluation of attitudes and values leading to personal transformation, rather than just breadth of knowledge (Gravett 2004:24-25). An analogy may be drawn here from the field of preaching where there is a distinct difference between superficial 'preaching the whole gospel' every week and going into a text deeply to discover in-depth meaning for listeners of sermons.

The SOLO multimodal model (Killen \& Hattingh 2004) provided a useful tool for both curriculum planning and the assessment tool, as it provides for greater understanding and focuses on quality learning from elementary to abstract levels through facilitator or learner dialogue:

This neoPiagetian model proposes five modes of thinking: sensori-motor, ikonic, concrete symbolic, formal and postformal. These modes are increasingly abstract and develop as an individual matures from infancy through to adulthood. Although each mode to some extent builds on the previous mode, each mode also continues to develop in its own right. (Callingham 1997:206)

As has been demonstrated, this cannot be simply an intellectual exercise but one which is influenced by the affective domain and has an ethical aspect.

\section{Ethical principles and ethical clearance}

'Scientific knowledge is intrinsically related to human values and interests. Research is therefore not only a scientific enterprise but also a moral enterprise' (St Augustine College 2009:1). Because people are involved (mentor, mentee, and subjects), these are necessary in all forms of research in order to protect participants in the research community. These include confidentiality, transparency, empowerment and freedom (McBride \& Schostak 1994a:1-2; cf. 1994b \& 1994c). To these we would add respect, beneficence and justice (St Augustine College 2009:1-2). Various aspects relating to ethical issues need to be negotiated such as access, accounts, boundaries and the purpose of the research (St Augustine College 2009:2). Lifelong learning has a place in the ethical domain because it encourages reflection on learning as well as learning by doing and understanding. The issue of spiritual formation in this regard has a strong affinity with life-long learning: 'Spiritual formation, along with moral formation, is a life-long process of discipleship, being formed on the likeness of Christ' (Kretzschmar 2004). This has a long history (Duncan 2010:64, 65, 66) as our forefathers led others in the Christian life by teaching and example.

\section{Content of the portfolio}

The outcome of assessment for the learners was a portfolio which allowed for diagnostic, formative and summative assessment. Primary documents included preparatory material (articles and excerpts), worksheets or assignments and student feedback. Secondary documents included self-evaluations and reflections (meta-cognition), peer observations, personal journals, goal statements and personal philosophies. A final cumulative report constituted the summative assessment.

It is also important for the facilitator to engage in a form of assessment. This can be done through peer review of the conduct of opportunities using a 'critical friend' (McNiff 2002:22). Part of the process of self-assessment includes an evaluation of the learners' perceptions of their relationship with the facilitator. It also needs to include an evaluation of how far the facilitator has achieved the degree of facilitation that was planned.

\section{A model from another continent}

After the learning model was designed in 2009, it was discovered that it has clear similarities to a model prepared in Brazil at the Evangelical Theological Seminary in Curitiba [FATEV] (Dysjeland 2012:40ff.). In our context the church's requirements 'for practical placements led the students 
straight into the context of the church's service' (cf. Dysjeland 2012:40) as a community engagement or service learning module. Theory and practice are inextricably linked in dialogue. The first year consists mainly of 'observational practice' (Dysjeland 2012:40) in order that students become familiar with the breadth and depth of the spiritual life they will encounter in ministry. Alongside this they participate in congregational placements. As they progress:

it is expected that the students should gradually take on increasing responsibility in their placements, and that towards the end of their degree they should demonstrate the ability to work both in a team and independently. (Dysjeland 2012:41)

All of this provides ample opportunity to test their calling through coming 'into close contact with the profession that the degree is directed towards' (Dysjeland 2012:41) and aims to provide learners with academic education and personal formation. The Lausanne Movement has summarised the situation well:

Necessarily any education must involve the passing on of content. However, effective education for world evangelisation must see as its goal the formation of values and attitudes as well as the communication of knowledge and skills. Effective education for evangelisation must, therefore, be transformational. (Lausanne 2005:2)

\section{Conclusion}

The aim of this project was to enable learners to discover ways of learning about the praxis of ministry through participating in their own learning process. Their prior experience provided a significant part of the resources for learning and additional material was used to stimulate and develop their critical thinking abilities. Taking account of the fact that ministry is a life-long teaching and learning exercise, the principle of lifelong learning is vital. It requires flexibility and self-regulated learning. Through interacting with learners, this provides ongoing opportunities for the facilitator to evaluate his own professional development and integrate new findings and insights leading to a more learner-centred focus in my practice as well as personal transformation.

\section{Acknowledgements Competing interests}

The author declares that he has no financial or personal relationship(s) which may have inappropriately influenced him in writing this article.

\section{References}

Callingham, R.A., 1997, 'Teachers' Multimodal Functioning in Relation to the Concep of Average', Mathematics Education Research Journal 9(2), 205-224, viewed 12 October 2010, from http://dx.doi.org/10.1007/BF03217311

Candy, P.C., 1996, 'Lifelong learning and the university sector', a discussion paper for the National Commission on Higher Education in S. Walters (ed.), 'Lifelong learning within higher education in South Africa: Emancipatory potential?', International Review of Education 45(5/6), 575-587, viewed 10 October 2010, from http://dx.doi.org/10.1023/A:1003847629351

Cooper, G., 2000-2006, 'The collaborative research model: Student learning teams in undergraduate research. Teaching Effectiveness Programme. University of Oregon', viewed 22 May 2008, from http://tep.uoregon.edu/resources/crmodel/ index.html

Copley, B., 2009, 'Holistic intelligence: Excellence through integration', in P.H. du Toit (ed.), Reader for postgraduate studies in professional development, facilitating learning and assessment, pp. 72-80, Department of Humanities Education, University of Pretoria, Pretoria.
De Boer, A., Steyn, T. \& Du Toit, P., 1999, A whole brain approach to teaching and learning in higher education, Centre of Academic Development, University of Pretoria, Pretoria.

Derek Bok Center, Harvard University, 2004, 'Teaching in racially diverse college classrooms', viewed 15 June 2009, from http://bokcenter.fas.harvard.edu/docs/ TFTrace.html

Don, C., 1998, 'Leadership Style Survey: A big Dog, Little dog and Knowledge Jump Production', viewed 14 October 2010, from http://www.nwlink.com/ donclark/ leader/survstyl.html

Duncan, G.A., 2010, 'Church Discipline: Semper reformanda as the basis for transformation', Journal of Theology for Southern Africa 136 (March), 57-75.

Du Toit, P.H., 2009a, Reader for postgraduate studies in professional development, facilitating learning and assessment, Department of Humanities Education, University of Pretoria, Pretoria.

Du Toit, P.H., 2009b, 'Overarching model for instructional design', in P.H. du Toit (ed.), Reader for postgraduate studies in professional development, facilitating learning and assessment, pp. 29-35, Department of Humanities Education, University of Pretoria, Pretoria.

Dysjeland, M., 2012, 'Theological education for a missional church - A perspective from a theological training institution in Brazil', in B. Fagerli, K. Jørgensen, R. Olsen, K.S. Haug \& K. Tveitereid (eds.), A learning missional church: Reflections from young missiologists, pp. 33-48, Regnum, Oxford.

Fagerli, B., Jørgensen, K., Olsen, R., Haug, K.S. \& Tveitereid, K. (eds.), 2012, A learning missional church: Reflections from young missiologists, Regnum, Oxford.

Felder, R.M. \& Soloman, B.A., 2009, 'Learning styles and strategies', in P.H. du Toit (ed.), Reader for postgraduate studies in professional development, facilitating learning and assessment, pp. 53-56, Department of Humanities Education, University of Pretoria, Pretoria.

Fiorenza, F.S., 1984, Foundational theology: Jesus and the Church, Beacon Press, Boston.

Gagnon, G.W. \& Collay, M., n.d., 'Constructivist learning design', viewed 14 October 2010, from http://www.prainbow.com/cld/cldp.html

Gardner, H., 1983, Frames of mind: The theory of multiple intelligences, Basic Books, New York.

Garrison, R. \& Kanuka, H., 2004, 'Blended learning: Uncovering its transformative potential in higher education', Internet and Higher Education 7, 95-105.

Gerkin, C.V., 1986, Widening the Horizons, Westminster, Philadelphia.

Gorski, P.C., 2004a, '20 (self) critical things I will do to be a better multicultural educator', viewed 08 October 2010, from http://www.edexchange.org/ multicultural/reseource/seslf_critique.html

Gorski, P.C., 2004b, '7 key characteristics of a multicultural education curriculum' viewed 12 October 2010, from http://www.edchange/multicultural/resources/ ct_characteristics.html

Gorski, P.C., 2004c, 'Six critical paradigm shifts for multicultural education (and the questions we should be asking)', viewed 14 October 2010, from http://www. edchange/multicultural/resources/paradigmshifts.html

Gorski, P.C. \& Covert, B., 1996, 2000, 'Defining multicultural Education', viewed 15 October 2010, from http://itari.in/categories/multiculturalism/ DefiningMulticulturalEducation.pdf

Gorski, P.C. \& Covert, B., 2004, 'Working definitions: Multicultural education', viewed 14 October 2010, from http://www.edchange.org/multicultural/initial.html

Gravett, S., 2004, 'Teaching and learning: Establishing communities of inquiry and interpretation', in S. Gravett \& H. Geyser (eds.), Teaching and Learning in Higher Education, pp. 22-40, Van Schaik, Pretoria.

Gravett, S. \& Geyser, H., 2004, Teaching and Learning in Higher Education, Van Schaik, Pretoria.

Greenleaf, R.K., 1977, Servant Leadership: A journey into the nature of legitimate power and greatness, Paulist Press, New York.

Groome, T.H., 1980, Christian religious education: Sharing our story and vision, Harper \& Row, San Francisco.

Groome, T.H., 1991, Sharing faith: A comprehensive approach to religious education and pastoral ministry, the way of shared praxis, Harper, San Francisco.

Gross Davis, B., 1999, 'Diversity and complexity in the classroom: Considerations of race, ethnicity and gender', viewed 12 October 2010, from http://.hcc.hawaii. edu/intranet/committees/FacDevCom/guidebk/teachtip/diverse.htm

Hattingh, A. \& De Kock, A., 2008, 'Perceptions of teacher roles in an experiencerich teacher education programme', Innovations in Education and Teaching International 45(4), 321-322.

Hodgkinson, C.A. \& Maree, J.G., 1998, 'Action research: Some guidelines for first-time researchers in education', Journal of Education and Training 19(2), 51-65.

Juvenal, n.d., 'D. lunii luvenalis Satiraes 345', viewed 09 October 2010, from http:// www.thelatinlibrary.com/juvenal/6.shtm

Killen, R. \& Hattingh, S.A., 2004, 'A theoretical framework for measuring the quality of student learning in outcomes-based education', South African Journal of Higher Education 18(1), 72-86.

Kolb, D.A., 1984, Experiential learning: Experience as the source of learning and development, Prentice-Hall, Eaglewood Cliffs, NJ.

Kouzes, J.M. \& Posner, B.Z., 2004, Christian reflections on the leadership challenge, John Wiley \& Sons, San Francisco.

Kretzschmar, L., 2004, 'The importance of moral and spiritual formation for the twentyfirst century', in E. Conradie (ed.), African Christian Theologies in Transformation, pp. 86-110, EFSA, Stellenbosch.

Kretzschmar, L., 2006, 'The indispensability of spiritual formation for Christian leaders', Missionalia 334 (2/3) August-November, 338-361. 
Lamoureux, P.A., 1999, 'An integrated approach to theological education', Theological Education 36, 141-156.

Lausanne Committee for World Evangelisation, 2005, 'Effective theological education for world evangelisation', Lausanne Occasional Paper 57, viewed 26 May 2011 from http:/ www.lausanne.org/documents/2004 forum/LOP57_IG28.pdf

McBride, R. \& Schostak, J., 1994a, 'An introduction to action research', viewed 21 October 2010, from http:www.enquirylearning.net/ Elu/Issues/Research/ Res1ch4.html

McBride, R. \& Schostak, J., 1994b, 'An introduction to action research', viewed 21 October 2010, from http:www.enquirylearning.net/ Elu/Issues/Research/ Res1ch6.html

McBride, R. \& Schostak, J., 1994c, 'An introduction to action research', viewed 21 October 2010, from http:www.enquirylearning.net/ Elu/Issues/Research/ Res1ch7.html

McNiff, J., 2002, 'Action research for professional development: Concise advice for new action researchers', viewed 25 June, from http://www.actionresearch.net; http://www.jeanmcniff.com

Myhre, P., 2010, 'Pedagogical Issues and Shifts Over the last Twenty-five Years in Theological Education in North America', in D. Werner, D. Esterline, N. Kang \& J. Raja (eds.), Handbook of theological education in world Christianity: Theological perspectives, ecumenical trends, regional surveys, pp. 295-301, Cluster, Pietermaritzburg.

Naidoo, M., 2008, 'The Call for Spiritual Formation in Protestant Theological Institutions in South Africa', Acta Theologica Supplementum 11, 128-146.
Preece, J., 2005, 'Conceptualising lifelong learning: North-south divides', working paper 2, Centre for Research and development in Adult and lifelong Learning, Department of Adult and continuing Education, University of Glasgow, Glasgow.

Preismerk, M. \& Buehler, P., 2010, 'Pedagogy and Methodology in Theological Education', in D. Werner, D. Esterline, N. Kang \& J. Raja (eds.), Handbook of theological education in world Christianity: theological perspectives, ecumenical trends, regional surveys, pp. 285-294, Cluster, Pietermaritzburg.

Ruiz, L.E.J., 2010, 'The Theological Curriculum in Accredited Graduate Theological Education: A commentary on a North American conversation', in D. Werner, D. Esterline, N. Kang \& J. Raja (eds.), Handbook of theological education in world Christianity: Theological perspectives, ecumenical trends, regional surveys, pp 271-284, Cluster, Pietermaritzburg.

St Augustine College, 2009, Policy on ethics in research, St Augustine College, Johannesburg.

Walters, S., 1999, 'Lifelong learning within higher education in South Africa: Emancipatory potential?', International Review of Education 45 (5/6), 575-587, viewed 14 October 2010, from http://dx.doi.org/10.1023/A:1003847629351

Werner D., Esterline D., Kang N. \& Raja, J. (eds.), 2010, Handbook of Theological Education in World Christianity: Theological perspectives, ecumenical trends and regional surveys, Cluster Publications, Pietermaritzburg.

'Constructivism', n.d., viewed no date, from http://en.wikipedia.org/wiki/ Constructivism_(learning theory) (last modified 14 February 2009).

Wingate, A., 2010, 'Training for Ministry in a Multi-Faith Context: A case study from Britain', in D. Werner, D. Esterline, N. Kang \& J. Raja (eds.), Handbook of theological education in world Christianity: theological perspectives, ecumenica trends, regional surveys, pp. 223-229, Cluster, Pietermaritzburg. 